Uskenbayeva Alma Muratbekovna, $\mathrm{PhD}$

Institute of Metallurgy and Ore Benefication. Almaty, Kazakhstan E-mail: almauskenbaeva@mail.ru, https://orcid.org/0000-0002-0540-5651 Shamelkhanova Nelya Amanjolovna, associate Professor at Satbayev University Almaty, Kazakhstan. E-mail: nashamelkhan@mail.ru

\title{
NANOMODIFICATION OF CAST IRONS
}

\begin{abstract}
The article discusses the possibility of modifying iron with the addition of nanomaterials having carbon nanostructures. Taking into account new ideas about the structure of the iron melt, qualitative nano-modification is possible, where the main is the management of the structural state of the melt and on this basis the management of the process of formation of additional crystallization centers.
\end{abstract}

Keywords: modification, nano-modification, carbon nanostructures, cast iron, melt.

Ускенбаева Алма Муратбековна, $\mathrm{PhD}$

Институт металлургии и обогащения. Алматы, Казахстан E-mail: almauskenbaeva@mail.ru,https://orcid.org/0000-0002-0540-5651

Шамельханова Неля Аманжоловна профессор Satbayev University. Алматы, Казахстан E-mail: nashamelkhan@mail.ru

\section{НАНОМОДИФИЦИРОВАНИЕ ЧУГУНОВ}

Аннотация. В статье рассмотрены возможности модифищирования чугуна с добавками наноматериалов имеющих углеродные наноструктуры. Учитывая новые представления о строении расплава чугуна возможно качественное наномодифицирование, где главным является управление структурным состоянием расплава и на этой основе управление проиессом образования дополнительных ичентров кристаллизащии.

Ключевые слова: модифицирование, наномодифичирование, углеродные наноструктуры, чугун, расплав.

Продукция из чугуна, стали и ферросплавов находит применение практически во всех отраслях промышленности являясь базой для развития машиностроения и металлообработки.

Для обеспечения качества этих изделий необходимо структурное управление расплавами чугуна, которое может осуществляться различными способами. Одним из наиболее широко распространенных способов управлять процессом структурообразования для обеспечения необходимых свойств является модифицирование [1].

В последние десятилетия актуальными становятся исследования процессов структурообразования и изменения свойств чугунов при введении наномодифицирующих добавок. В качестве эффективных нанодобавок повышенный интерес вызывают углеродные наноструктуры, вследствие уникальности их свойств и соответствующей возможности эффективного использования на практике.

Наноструктурные углеродные добавки к модификаторам чугунов интересны еще и тем, что появились новые представления о строении чугуна где расплав рассматривается с содержанием углеродных нанокомплексов, фуллереноподобных структур. Согласно структурной иерархии углеродных структур [2], процесс кристаллизации пластинчатого и шаровидного графита чугунов сопровождается образованием фуллеренов, кластеров, эндоэдралов, наночастиц, фрактальных агрегатов, кристаллов графита. Основываясь на 
этом, в статье дается описание о возможности применения новых видов модифицирования с добавками наноуглеродных структур.

Нанотехнологии активно внедряются во все отрасли промышленности и науки, и применение наноструктур в литейном производстве не исключение. В работе [3], показано влияние наноструктурных добавок с повышенной химической активностью углерода и кремния на фазообразование при затвердевании серого чугуна с помощью закалки из жидкого состояния. Проведены исследования ультрадисперсного модификатора с высоким содержанием углерода и кремния, полученные из отходов металлургического производства. Результаты этих исследований по графитизирующей способности модификатора с наноструктурами показал, что его ввод в расплав серого чугуна позволяет снизить выделение свободного феррита в микроструктуре чугуна до 5-8\% при неизменной твердости 207-217HB, а также способствует получению наиболее благоприятной морфологии графита (росту более крупных пластинок графита одинакового размера) и более равномерному его распределению по объему металлической матрицы. Установлено наличие включений шаровидного графита. Увеличивается содержание перлита в матрице, и показано, что ввод нанодобавок влияет на морфологию графита в чугуне. Такое наномодифицирование привело к образованию структуры графита смешанной формы, что объясняет высокий комплекс механических свойств после модифицирования нанодобавками благодаря формированию графита глобулярной формы в объеме слитка.

В работе [4] приведены результаты спектральных исследований строения различных наноструктурированных форм углерода (графена, углеродных нанотрубок, фуллереновой черни), которые вводили в состав комплексного модификатора с целью получения качественных чугунных отливок с благоприятной структурой графита и металлической матрицы. Применение таких углеродных наноструктур обусловлено тем, что углерод является сильнейшим графитизатором, который входит в состав многих перспективных комплексных модификаторов. Качество таких модификаторов связывают с их строением, дисперсностью, содержанием вредных примесей.

Ранее нами были проведены экспериментальные исследования [5] по модифицированию высокопрочного чугуна наноуглеродными добавками, с целью оценки модифицирующей способности наноматериала на степень графитизации. Полученные результаты количественного металлографического анализа показали увеличение числа графитных включений, более равномерное их распределение в плоскости шлифа, а также полное отсутствие цементита в металлической матрице. Механические и трибологические испытания подтверждают, что углеродная наноструктура в виде фуллереновой черни (ФЧ), увеличивает степень графитизации чугунов, и является усилителем действия основного модификатора. Показано, что углеродные наноструктуры как готовые наноповерхности являются затравками с заданной кристаллографической ориентацией. В процессе модифицирования, ФЧ усиливает диффузию углерода, находящегося в расплаве чугуна в виде фуллереноподобных структур. Это приводит к флуктуации концентраций и свободной энергии, а следовательно, становится причиной резкого увеличения числа центров графитизации и ускорения всего процесса графитизации в целом [5].

Применение наноструктурных материалов в модифицировании (наномодифицирование) довольно перспективно, так как является довольно эффективным способом управления структурой, получившим широкое распространение вследствие развития нанотехнологий. Наномодифицирование является более точным модифицированием [2], потому что наномодифицирование управляет только процессами зарождения и роста центров кристаллизации (графитизации) и модификаторы не участвуют в процессах легирования, раскисления, дегазации, десульфурации. 
Наноструктурным модификаторам (наномодификаторам) присваиваются свойства поверхностно-активных элементов (ПАЭ) [2]. Так в работе [6] обоснована целесообразность применения наноструктурированных углеродных материалов (графена, фуллереновой черни) в качестве эффективной добавки к модификатору чугунов. Экспериментальные результаты по получению качественных чугунных отливок с наноуглеродными добавками в присутствии комплексного модификатора подтверждают улучшение структурных и триботехнических характеристик чугуна. Показана перспективность использования фуллереновой черни (ФЧ) как сравнительно дешевого побочного продукта фуллереновой нанотехнологии, обладающего улучшенными трибологическими свойствами. Механизм графитизации модифицированного ФЧдобавками серого чугуна раскрывается на основе имеющихся и полученных результатов исследований в области наномодифицирования.

Многие исследования ученых показывают, что с помощью наномодифицирования можно решать такие задачи как модифицирование различных чугунов при получении отливок; создание технологии безотходной утилизации отвальных шлаков медноникелевого и титанового плавильного производства в качестве дешевого шихтового материала и полиметаллического ферросплава, а также создание малоэнергоёмкой технологии получения ковкого чугуна [3].

Таким образом, современные тенденции развития способов модифицирования чугунов связаны с разработкой эффективных рациональных составов модификаторов, которые могли бы обеспечить оптимальные структуры отливок, а также технологичность обработки, предполагающей простоту введения модификатора в расплав, безопасность и экономичность процесса модифицировании.

До недавнего времени было известно, что углерод в чугуне находится в свободном состоянии, в виде химического соединения (карбида), и в твердом растворе. Однако исследования многих ученых показывают, что углерод может находится в разных модификациях, в том числе и в жидком расплаве чугуна [7-9]. Последние достижения в области углеродных соединений связывают с тем, что в железо-углеродистых сплавах возможно образование свободного углерода в виде фуллеренов, бакитьюбов и глобул [9].

Таким образом, в исследованиях различных ученых и практиков многообразие углеродных форм объединяется их фуллереновым строением. Исходя из современных представлений о фуллереной природе чугунов, по новому оценивается влияние модифицирования на структурообразование в графитизированных чугунах. Учитывая присутствие наноструктур в расплаве, можно сказать, что углеродные наночастицы выступают концентрированными источниками атомов углерода, представляющие собой гомогенные центры кристаллизации графита, а также адсорбируясь на поверхности неметаллических включений при кристаллизации, делают эти включения активными гетерогенными центрами графитизации. Воздействие на структуру расплава фуллеренов в процессе модифицирования приводит к образованию эндоэдральных наносоединений, изменяющих характер кристаллизации. Такое модифицирование относят к наномодифицированию.

Существования фуллеренов в структуре чугунов и сталей, дает по-новому представление о роли углерода в формировании структуры железоуглеродистых сплавов. Наноструктурный углерод оказывает существенное влияние на физико-механические свойства стали и чугунов, за счет своего участия в структурных и фазовых превращениях. Вместе с тем присутствующие в расплаве фуллерены могут являться центрами кристаллизации. В исследованиях механизма образования центров кристаллизации графита в чугунах на молекулярном уровне, в рамках термодинамической модели 
квазиравновесных систем было высказано предположение, что ими должны быть полиэдральные идеальные структуры, напоминающие фуллерены [9-10].

Из вышеизложенного следует, что методы модифицирования чугунов с использованием принципиально новых подходов, учитывающих наличие фуллеренов в железоуглеродистых расплавах, довольно активно развиваются. В отличие от традиционного модифицирования в основе которого лежит создание дополнительных центров кристаллизации, в наномодифицировании главным является управление структурным состоянием расплава и на этой основе управление процессом образования дополнительных центров кристаллизации.

Таким образом, можно сказать, что наномодифицирование чугуна с добавками углеродных наноструктур проходит за счет избирательного воздействия на фуллереновые комплексы и углеродные наночастицы, содержащиеся в железоуглеродистом расплаве. При этом сохраняется традиционная ковшевая технология ввода модификатора, применяемая в литейном производстве. И углеродные наноструктуры (в виде графена, углеродных нанотрубок, фуллеренов, фуллерновой черни и сажи), используемые как добавки при модифицировании, могут стать привлекательными для промышленного освоения, так как обеспечивают улучшение свойств, не требуя при этом изменения технологической линии при выплавке изделий.

\section{ЛИТЕРАТУРА}

1. Илюшкин Д.А., Давыдов С.В., Болдырев Д.А. Наномодифицирование чугуна для отливок стеклоформ // Вестник Брянского государственного технического университета. - 2017. - № 2 (55). - С. 113-119.

2. Давыдов С.В. Наномодификатор как инструмент генной инженерии структурного состояния расплава чугуна. // Машиностроение. - 2008 - №6. - С. 6-13.

3. Кондратьев В.В., Мехнин А.О., Иванов Н.А. Исследования и разработка рецептуры наномодифицированного чугуна для ниппелей анодов алюминиевых электролизеров // Металлург. - 2012 - №1 - С. 69-71.

4. Ускенбаева А.М. Шамельханова Н.А., Волочко А.Т. Спектральные исследования углеродных наноструктур, используемых в качестве модификаторов чугунов. // Комплексное использование минерального сырья. Алматы. 2016. - №1 - - С.61-65.

5. Shamelkhanova N.A., Uskenbayeva A.M., Volochko A.T., Korolyov S.P. The Study of the Role of Fullerene Black Additive during the Modification of Ductile Cast Iron. // Materials Science Forum. Switzerland. 2017. - Vol. 891, - P. 235-241.

6. 6. Ускенбаева А.М., Волочко А.Т., Шамельханова Н.А., Королев С.П., Шегидевич А.А. Влияние наноуглеродных добавок на графитизацию и трибологические совйства серого чугуна. // Металлург. - 2016. - №2. - С. 64-69.

7. Жуков А.А. О формах существования углерода в чугунах // МиТОМ, - 1992. - № 11. - C. 34.

8. Кимстач Г.М., Уртаев А.А., Молодцова Т.Д. О существовании карбина в структуре аустенитного чугуна // МиТОМ. - 1991.- №2 - С. 17-18.

9. Закирничная М.М. Фуллеренная модель структуры железо-углеродистых сплавов. - Уфа: Препринт.: Изд-во УГНТУ, 1996. - 35 с.

10. Давыдов С.В. Современные представления о диаграмме $\mathrm{Fe}-\mathrm{C}$ и современное состояние отечественных исследований в этой области. // Международная научнотехническая конференция. Наука и технология модифицирования чугуна. (НиТМЧ2018, Наб.Челны). http://www.modificator.ru/about/2018_conference_actual.html. 